A
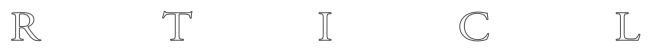

KaARle WirTa

https://orcid.org/0000-0001-7594-0804

Tampere University

KaTja Tikka

https://orcid.org/0000-0001-8426-6890

University of Helsinki

JAAKKO BJÖRKLUND

https://orcid.org/0000-0003-4068-4809

University of Helsinki

\title{
ADMINISTERING EMPIRE. BUSINESS DIPLOMACY IN EARLY MODERN SWEDEN: THE CASES OF ABRAHAM CABILJAU AND THE GOTHENBURG COMPANY
}

\begin{abstract}
The article illustrates the importance of business diplomacy practised by free agents, who navigated and negotiated between northern European empires for widespread commercial, legal and administrative developments. Abraham Cabiljau's career is an example from the early modern Swedish empire, which stands on the threshold of a new era. In the Swedish empire, Cabiljau was involved in several different sectors, from military recruitment to the development of state accounting and administration of international trade. He represents the Swedish empire's vast economic relationships with international merchant networks operating in a broad spectrum of military and commercial arenas. The Swedish empire was economically dependent on the financial resources of the merchants in Amsterdam, and economic prosperity was not the sole contribution of these merchants. The education, knowledge and connections provided by Cabiljau greatly enhanced the administration and organisation of Sweden's international trade by importing a new legal mindset and organisational culture. In return, northern mining resources and Baltic commerce were alluring for Dutch merchants. We argue that the modelling of international organisations was an
\end{abstract}


essential part of Swedish economic development. However, the first Swedish trading companies remained an experimental attempt to transplant the Dutch East India Company (VOC) model to Sweden. Individuals like Cabiljau represent key actors who ignited, taught and promoted commercial law development in Sweden, on which international commerce was later built upon, with long-lasting impacts.

Keywords: Sweden, Dutch Republic, Gothenburg, administration, business diplomacy, organisations, trading company, legal borrowing

\section{INTRODUCTION}

In 1609, Abraham Cabiljau (Cabeliau, Cabillau) (1571-1645), a merchant from Amsterdam, was appointed mayor of Gothenburg, a recently established settlement on the West Coast of Sweden. ${ }^{1}$ Gothenburg was the apple of the eye of the Swedish King Charles IX, who was eager to awaken and promote Swedish international trade. The appointment of Cabiljau was directly related to the endeavour to expand the power of the Swedish Crown. This project would be of pivotal significance for the development of the Swedish Empire. At the time, Sweden lacked experience in organised forms of international trade, so the king called upon foreign experts like Cabiljau to advance this undertaking. Throughout his career, Cabiljau played a crucial role in the structural development of Swedish foreign commerce. ${ }^{2}$

This article charts the career and business diplomacy of Abraham Cabiljau and his role in the development of Swedish international trade in facilitating military recruitment, especially concerning the establishment of the first Swedish trading companies. By using Cabiljau

1 The city of Gothenburg was granted staple rights in 1621, something which served to stabilise the existence of the settlement. Bertil Andersson, Martin Fritz, Kent Olsson, Göteborgs historia. Näringsliv och sambällsutveckling: 1 Från fästningsstad till handelsstad 1619-1820 (Stockholm: Nerenius \& Santérus, 1996), pp. 51-57.

${ }^{2}$ G. Jacobson, 'Abraham Cabiljau', in Svenskt biografiskt lexikon, https://sok. riksarkivet.se/sbl/artikel/16310 (accessed 16 Nov. 2020); Nils Erik Villstrand (ed.), Sveriges historia 1600-1721 (Stockholm: Norstedts, 2011), p. 478; Raimond Veenstra, 'Göteborgs första handelskompani (1606-1611): vem och varför? - Handelskolonin i Karl IX:s Göteborg betraktad ur en europeisk synvinkel', Göteborg för och nu (Göteborg: Göteborgs Hembygdförbunds Skriftserie XXXII 2008), 124; Lars Magnusson, Sveriges ekonomiska historia (Studentlitteratur: Lund 2016), p. 134. 
as an exemplary case study, the importance of the Dutch institutional environment for the Swedish Empire will be elucidated. Why did Gothenburg become an early centre for Cabiljau's business diplomacy, and how were organisational models adapted to new institutional environments?

Cabiljau was not exceptional within the context of the Swedish Empire but was instead representative of a larger group of experienced foreign merchants that migrated and established trade connections in Sweden. ${ }^{3}$ Several influential foreign merchants, such as the de $\mathrm{Geer}^{4}$ and the Momma 5 families, have been extensively studied due to their crucial role as creditors and investors in Swedish imperial expansion. ${ }^{6}$ However, in this article, the focus is not on the capital and credit provided by these merchants, but rather on the contribution of individuals, via business diplomacy, to the awakening and early organisation of Sweden's international trade.

In this article, business diplomacy refers to the actions of agents and organisations (trading companies) undertaken not only to achieve

${ }^{3}$ On the concept of free agents, see Cátia Antunes, 'Free Agents and Formal Institutions in the Portuguese Empire: Towards a Framework of Analysis', Portuguese Studies, 28, no. 2 (2012), 173-85; Kaarle Wirta, Early Modern Overseas Trade and Entrepreneurship: Nordic Trading Companies (New York, Routledge, 2020).

${ }^{4}$ Louis De Geer (1587-1652) was a notable Dutchman whose economic impact in Sweden was undeniable. His interests concerned especially Swedish copper and iron, the processing of which he organized successfully in Sweden for the first time. The Swedish Crown was dependent on his assets and he had close relations to the Monarch. Lars Magnusson, 'Bruksmiljö och brukskultur' in Stormaktstiden, ed. by Jacob Christensson (Lund: Signum svenska kulturhistoria, 2005), 334; Erik Wilhelm Dahlgren, Louis de Geer, 1587-1652, hans lif och verk, vol. 2 (Uppsala: Almqvist och Wicksell, 1923), p. 116.

${ }^{5}$ Leos Müller, The Merchant Houses of Stockholm c. 1640-1800. A Comparative Study of Early-Modern Entrepreneurial Behaviour (Uppsala: Uppsala University Library, 1998), pp. 55-62.

${ }^{6}$ Maj-Britt Nergård, Mellan krona och marknad: utländska och svenska entreprenörer inom svensk järnhantering frän ca 1580 till 1700 (Uppsala: Acta Universitatis Upsaliensis, 2001); Michiel de Jong, 'Dutch entrepreneurs in the Swedish Crown trade in copper and iron, 1580-1630', in Trade, Diplomacy and Cultural Exchange. Continuity and Change in the North Sea Area and the Baltic, ed. by Hanno Brand (Hilversum: Uitgeverij Verloren, 2005), pp. 36-57; Leos Müller, 'The Dutch Entrepreneurial Networks and Sweden in the Age of Greatness', in Trade, Diplomacy and Cultural Exchange, pp. 58-74. 
advantageous positions in trade exchanges, especially in new or alien institutional environments but also to combat uncertainty and risk. These actions, which are familiar from the field of diplomacy, included a variety of means. For example, one relevant issue was how to navigate and negotiate within contemporary international legal frameworks, such as the question of the right to conduct trade in specific areas or with specific goods. At the heart of business diplomacy, there were also questions regarding rights or duties on tariffs, tolls and customs, and how to develop and administer trading companies and other organisations in practice. ${ }^{7}$

This article argues that business diplomacy was essential to the expansion and development of the Swedish Empire by facilitating its successful interaction with international currents of trade. Cabiljau and his social networks brought to Sweden not only their capital and experience but a new legal mindset and organisational culture. By following the progression of Cabiljau from businessman to royal advisor, it is demonstrated how he influenced the modelling of Swedish international trading organisations. Cabiljau was generally competent and was thus well-equipped to provide the Swedish Empire with the necessary connections and expert knowledge regarding commercial law. ${ }^{8}$ This worked to everyone's benefit while at the same time boosting his own status in Swedish circles until his career ran up against certain limits. Furthermore, this article shows that although Cabiljau worked for the Swedish Empire, the interests of empire and merchant could at times pull in opposite directions. Ultimately, his case demonstrates why and how international connections and expertise in business, as imported by migrant foreigners, became rooted in the Swedish Empire with long-lasting consequences.

7 On early modern business diplomacy, see Cátia Antunes, 'Early Modern Business Diplomacy: An Appraisal', Diplomatica, 2, no. 1 (2020), 20-27.

8 About expertise and knowledge in the early modern empire building, see Kortekangas and Schiavone in this issue. 


\section{THE INSTITUTIONAL ENVIRONMENT OF THE DUTCH EMPIRE}

From the late sixteenth to the mid-seventeenth century, the Dutch Empire was one of the strongest commercial empires in Northern Europe. ${ }^{9}$ After the Dutch provinces had revolted against Spanish rule in 1566, the seven northern provinces came together to form the Dutch Republic. In turn, liberation from Spanish rule gave rise to various business cycles, which slowly made the Republic prosper and grow as a maritime empire. Merchants of the Dutch Republic had the education, means, experience, expertise and capital to develop international trade during a period of accelerating European maritime expansion. Since the end of the sixteenth century, many merchants in the Republic, especially in Amsterdam, had accumulated enormous wealth, predominantly in the booming maritime and shipping sectors. Dutch trade within the Baltic, Mediterranean, North Sea and increasingly the colonial sphere also benefited from refined institutional developments, such as merchant banks, insurance services, trading companies and stock exchanges. ${ }^{10}$

Although these inventions were not entirely novel nor restricted to the Republic, the Dutch were able to pick up the pace and volume of international commerce. At the organisational level, Dutch trading companies such as the Dutch East India Company (VOC), Dutch West India Company (WIC) and Noordsche Compagnie were pioneers in organising and administering international trade. ${ }^{11}$ From a business perspective, the bottom line of these innovations was to reduce risk and combat uncertainty, both of which were pervasive in early modern

9 On the genealogy of the Dutch empire, see Jonathan Israel, Dutch Primacy in World Trade, 1585-1740 (Oxford: Clarendon Press, 1990).

10 On the importance of the Dutch economy in this period, see e.g. Jan de Vries and Ad van der Woude, The First Modern Economy: Success, Failure, and Perseverance of the Dutch Economy, 1500-1815 (Cambridge-New York: Cambridge University Press, 1997); Clé Lesger, The Rise of the Amsterdam Market and Information Exchange: Merchants, Commercial Expansion and Change in the Spatial Economy of the Low Countries, c. 1550-1630, trans. by J.C. Grayson (Aldershot: Burlington, Ashgate, 2006).

11 Niels Steensgaard, 'The Dutch East India Company as an Institutional Innovation', in Dutch Capital and World Capitalism: Capitalisme Hollondais et Capitalisme Mondial, ed. by Maurice Aymard (Cambridge: Cambridge University Press, 1982), pp. 235-58. 
maritime commerce. In turn, the legal outlook on long-distance trade required commonly agreed rules (new legislation), especially in cases where partners did not know each other personally and issues of responsibility needed to be solved. ${ }^{12}$

At the heart of the developing maritime sector was Amsterdam. Since the fall of Antwerp in 1585, the city had begun to attract potential trading partners from abroad thanks to its tolerant regulations regarding religion and capital distribution. From all over Europe, immigrants arrived to establish trade in the city. While many were impelled to move because of religious intolerance elsewhere, others were drawn by the prospects of the ascendant trading sector. ${ }^{13}$

During the seventeenth century, the Republic grew important for Swedish international trade, and Dutch ports cities such as Amsterdam became the central nodes of the international import and export sector. ${ }^{14}$ For the Nordic kingdoms, Amsterdam offered considerable opportunities, and many Scandinavians found employment with Dutch trading houses, commercial companies, and the military. ${ }^{15}$ Others, especially elite members, gravitated towards Leiden and other renowned Dutch universities to pursue the knowledge and skills needed within the growing state administration but which were helpful for commercial purposes as well. ${ }^{16}$

The institutional environment of the Dutch Empire was inspiring, educating and potentially also profitable for Swedish subjects, thanks

12 Johan Söderberg, Vår världs ekonomiska historia - Del 1 - Den förindustriella tiden (Stockholm: SNS förlag, 2007), pp. 95-96.

13 Israel, Dutch Primacy, pp. 25-32; Jelle van Lottum, Across the North Sea: The Impact of the Dutch Republic on International Labour Migration, c. 1550-1850 (Groeningen: Aksant Academic Publishers, 2008).

14 Åke Sandström, Mellan Torneå och Amsterdam: En undersökning av Stockholms roll som förmedlare av varor i regional- och utrikeshandel 1600-1650 (Stockholm: Stockholmsmonografier 1990), pp. 320-30.

15 Ewert Wrangel, De betrekkingen tusschen Zweden en de Nedelrnaden op het gebied van letteren en wetenschap: voornamlijk gedurende de zeventiende eeuw (Leiden: Brill 1901), p. 114; Van Lottum, Across the Northern Sea.

16 Marianne Vasara-Aaltonen, Learning Law and Travelling Europe: Study Journeys and the Developing Swedish Legal Profession, c. 1630-1800 (Leiden: Brill, 2020), pp. 75-77, 294-300; Wrangel, De betrekkingen, pp. 51-52, 115. 
to the international contacts that it fostered. When Sweden started to build its commercial sector, foreigners were needed to teach Swedes how to develop international trade and introduce new business partners. ${ }^{17}$ In the first half of the seventeenth century, individuals like Cabiljau stood at the centre of such developments.

Cabiljau's background and early career were typical of the international merchants who emerged from this Dutch institutional environment. Although born in Leiden, Cabiljau's family originated from Ghent in the southern Low Countries and belonged to migrating merchant communities. An apprenticeship followed studies at Leiden University at a trading house in Amsterdam. In 1599, Cabiljau joined a Dutch expedition to the Guiana Coast as a bookkeeper and wrote a detailed journal, considered the first Dutch travel journal of the Caribbean world. In the journal, he disclosed how members of the expedition had communicated and traded with the indigenous population.

Although Cabiljau was not the first European on the Guiana Coast, his accumulated stock of information was a crucial component of the Dutch maritime expansion. After returning from his expedition, he delivered his journal to the States-General and subsequently contributed another work on international maritime navigation. Cabiljau's educational background and distribution of knowledge from the expedition attest to both his theoretical and practical experience of managing business in new environments. ${ }^{18}$

\section{GOTHENBURG - TO ANCHOR INTERNATIONAL TRADE}

At the same time that Cabiljau was learning his trade in Amsterdam and Guiana, Sweden underwent a brief but brutal civil war, during which

17 The Swedish elite studied in Leiden in order to return to Sweden and use their experience to improve the capacity of the central Swedish state organisations. However, this transition took time, and only after the 1650s had the Swedes accumulated enough experience to take on a larger share of these tasks.

18 Lodewijk Hulsman, 'Nederlands Amazonia: handel met indianen tussen 1580 en 1680', PhD-Dissertation (Amsterdam, University of Amsterdam, 2009), p. 29; Nationaal Archief, Den Haag, Staten-Generaal, nummer toegang 1.01.02, inventarisnummer 12563.2; Hugo Fröding, Berättelser ur Göteborgs äldsta historia (Göteborg: Wald. Zachrissons förlag, 1908), p. 8. 
the Calvinist-leaning Duke Karl of Södermanland (King Charles IX from 1604 to his death in 1611) usurped power from his vehemently Catholic nephew Sigismund I Vasa. This conflict was to have significant implications for the country's political, economic, and religious development, providing the basis for Cabiljau's subsequent career in Sweden and the opening up of new opportunities for business diplomacy.

Like his father before him, Charles IX was economically minded. The ongoing war against Sigismund (also king of Poland-Lithuania) was expensive. This encouraged the new monarch to launch numerous initiatives to improve Sweden's economic output in general and the Crown's revenues in particular. The mining and metal industries were enlarged and developed, and new cities and commercial institutions were established. Charles IX employed military and political means to pursue control over lucrative east-west commercial routes not only in the Baltic Sea but also in the Northern Arctic, a route that English and Dutch traders increasingly used. ${ }^{19}$ In each of these branches, Sweden needed the help of foreign experts, foreign capital and a foreign workforce to succeed.

A crucial component of these efforts was establishing the city of Gothenburg on the geopolitically significant sliver of the Swedish coastline between (hostile) Danish Halland and Norwegian Bohuslän. ${ }^{20}$ As Sweden's sole port with direct access to the North Sea, Gothenburg offered the means to circumvent the Danish controlled Sound and the tolls levied by the Danish king on all commerce to and from the Baltic Sea. Furthermore, Gothenburg's strategic position on the mouth of the river Göta promised to facilitate overseas trade by connecting the

19 The ongoing war in Estonia and Livonia, Charles IX's invasion and occupation of north-western Russia and conflict with both Norway and Russia over Northern Lapland were all part of this effort to gain control of trade routes. Mirkka Lappalainen, Maailman painavin raha: Kirjoituksia 1600-luvun Pohjolasta (Helsinki: Siltala, 2006), pp. 13-30; Sveriges Krig 1611-1632, vol. 1: Danska och Ryska Krigen (Stockholm: Victor Pettersons Bokindustriaktiebolag 1936), pp. 323-25; Michael Roberts, Gustavus Adolphus: A History of Sweden 1611-1632, vol. 1 (London: Longmans, 1965), pp. 38-46.

${ }^{20}$ The early trading activities and the foreign influence during the formative years of the town have been researched by Raimond Veenstra and Christina Dalhede, Viner, Kvinnor och kapital (Partille: Warne förlag, 2006). This work has been essential to understanding how the city hosted foreign merchant communities and how the city was developed. 
North Sea and Atlantic trade with riverine access to lake Vänern and the Swedish heartland. ${ }^{21}$

Foreign influence in Gothenburg was strong from its inception. The first city privileges, written in 1603 (confirmed by Charles IX in 1607), were inspired by Dutch city charters. ${ }^{22}$ In 1604 , the Swedish king broadcast an invitation for foreign merchants to migrate to the city, promising freedom of religion, as well as lavish exemptions from tolls. The message was well-received, and many Dutch, Scottish and German merchants, some of whom already had contacts in the region, answered the call. ${ }^{23}$ This group included several Dutch Calvinists, such as Cornelius Cornelisson, Abraham Cabiljau, Jacob van Dijck and Peter Coymans. ${ }^{24}$

Despite the increasing interest and growing flow of immigrants, Gothenburg's early development was marred by difficulties. Escalating Danish-Swedish tensions cast a long shadow, and during the ensuing Kalmar War (1611-1613), the fledgling city was ravaged by Danish troops. The ongoing Danish occupation (until 1619) combined with the separate Twelve Years' Truce (1609-1621) between the Dutch Republic and Spain discouraged Dutch migration. ${ }^{25}$ However, with the resumption

${ }^{21}$ On the local history of Göteborg and its early years, see Fröding, Berättelser; Helge Almquist, Göteborgs historia: grundläggning och de första hundra åren (Göteborg: Göteborgs litografiska aktiebolag, 1929); Andersson, Göteborgs historia, pp. 51-57; Veenstra, 'Göteborgs första handelskompani'.

22 The area previously known as Nya Lödöse, which had already established some trade with foreign merchant networks. Katja Tikka, Laivojen tuomaa lakia (Helsinki: Unigrafia, 2020), pp. 45-46.

23 See Alexia Grosjean and Steve Murdoch, 'The Scottish Community in Seventeenth-Century Gothenburg', in Scottish Communities Abroad in the Early Modern Period, ed. by Alexia Grosjean and Steve Murdoch (Leiden: Brill, 2005), pp. 191-223.

${ }^{24}$ Fröding, Berättelser, p. 43. Similarly, the Danish King Christian IV also invited foreigners, especially from the Low Countries, to move to Glückstadt (at the time a part of the Danish Empire). See Kaarle Wirta and Edgar Pereira, 'A Forgotten Emporium: Commercial Aspirations and Transnational Mercantile Networks in Seventeenth Century Glückstadt', in Locating the Global Spaces, Networks and Interactions from the Seventeenth to the Twentieth Century, ed. by Holger Weiss (Oldenburg: De Gruyter, 2020), pp. 17-40.

${ }^{25}$ In 1612, as a part of the Kalmar War, the Danes had attacked the fort of Älsvborg, adjacent to Gothenburg, and forced Sweden to ransom it for a sum of one 
of hostilities in the Netherlands in 1621, the city proliferated; a steady flow of migration from the Low Countries continued until mid-century. ${ }^{26}$ Trade between Gothenburg and Amsterdam was lively. For example, in 1622, Jan Beucken gave power of attorney to Jacob de Rees, from Amsterdam, in agreement with the Swedish king to promote the trade between the two towns. ${ }^{27}$

To understand the importance of the expertise and knowledge that the Dutch merchants brought with them, it is crucial to observe the push and pull factors behind migration. According to Veenstra, religion was only part of the rationale for migration. The economic opportunities (pull factors) that Gothenburg provided for merchants from the Low Countries were Far more important. In fact, of the merchants who arrived in Gothenburg, the majority had come from the southern parts of the Netherlands through an initial stay in Amsterdam. ${ }^{28}$

In Amsterdam, native merchants already dominated the most lucrative trading sectors, making it difficult for these immigrants to partake in Baltic commerce, known as the 'moeder negotie' (the mother trade). Since the Baltic trade was also the preserve of the city's political elite, such exclusion also deprived immigrants of political influence and access. These factors compelled immigrant merchants to stake their claim in new areas, such as Gothenburg. In short, the local Amsterdam system pushed these merchants to use their capital and expertise in relatively new business areas. These merchants were double immigrants - first to Amsterdam and from there onwards to Gothenburg. ${ }^{29}$

million rixdalers, which the Sweden paid in four instalments. In 1619, the Swedes reclaimed the fort and territory. This was paid extensively through Dutch capital.

26 For extensive research on the early foreign contacts of Gothenburg and its trade, see e.g. Dalhede, Viner kvinnor kapital; Wrangel, De betrekkingen.

27 Stadssarchief Amsterdam (hereafter cited as SAA), Notarieel Archief (hereafter cited as NA), 218, fol. 97, 30 May 1622.

28 Veenstra, 'Göteborgs första handelskompani'. On the Dutch migration to Göteborg, see, Fröding, Berättelser, pp. 45-49.

29 Ibid.; Milja Van Tielhof, The 'Mother of All Trades': The Baltic Grain Trade in Amsterdam from the Late 16th to the Early 19th Century (Leiden: Brill, 2002), e.g. chapter one, especially pp. 25-27. 


\section{CABILJAU SERVING GOTHENBURG}

Abraham Cabiljau was one of the first to respond to the king's invitation to migrate to Sweden. ${ }^{30}$ Cabiljau had already been involved in recruiting Dutch families to migrate to Gothenburg prior to 1604 , when he himself moved to Sweden. It seems likely that Cabiljau was introduced to the king by an older master shipwright, Cornelius Corneliusson, who was director of the shipyard at Älvsborg. ${ }^{31}$

Business diplomacy had already been deployed in the negotiations concerning the foundation of Gothenburg, as Cabiljau presented the idea of a trading company that would benefit Swedish and Dutch trade being included in the founding privileges. Trade with Persia and Muscovy was mentioned as a preferential sector, which was hardly surprising. Access to these trading circuits was one of the critical reasons for Dutch merchants to migrate to Sweden. ${ }^{32}$ Further incentives included the prospect of gaining a share of Baltic commerce through Sweden, which was not available in Amsterdam and the chance of circumventing the Sound toll. During this period, all ships passing through the Danish Sound had to pay a toll to continue their voyage to and from the Baltic.

These ambitions quickly led to the establishment of the first Swedish General Trading Company (Gothenburhsche Compagnie van Coophandel), as Cabiljau and his business associates proposed. ${ }^{33}$ The company, which received the king's patent (charter) in September 1607,

30 Fröding has suggested that roughly 170 people moved from the Republic to Gothenburg, Fröding, Berättelser, p. 49.

31 Tikka, Laivojen tuomaa lakia, pp. 41-42. A letter dated 14 March 1603, Folke Lindberg and Folke Sleman Privilegier, resolutioner och förordningar för Sveriges städer IV (1592-1611) (Stockholm: Stadshistoriska institutet, 1949), pp. 310-11; Fröding, Berättelser, p. 8.

32 Anders Anton von Stiernman, Sweriges Rikes commerce, politie och oeconomie uti gemen uppå Hans Kongl. Maj:ts nodigsta belfallning, vol. 1 (Stockholm: Kong. trykeriet, 1747), pp. 538-40.

33 Curiously, the company did not even carry a Swedish name. Cabiljau's associates consisted of Paridon von Hoorn, Pieter Coymans, Pieter Ranst and Israel Wijdts. This network consisted of relatively young men (between 16 and 38 years old), who began their careers in Gothenburg. Later, many of them participated in Dutch trading companies, like the Dutch East India Company, the Noordsche Compagnie and the Dutch West India Company. Veenstra, 'Göteborgs första handelskompani', 122. 
was set up to operate as the exporter of Swedish goods abroad. The participants were to trade in both imports and exports, focusing primarily on goods from Russia via Sweden to international markets. However, Swedish goods like timber, tar, copper and furs were also to be exported. From the king's perspective, exports were needed to finance the state's military apparatus. From the point of view of international merchant networks, Cabiljau and his associates, in turn, became brokers of mercantile interests in Sweden. This proposal was well-received, and in 1607, Cabiljau became one of the directors of the newly established company. ${ }^{34}$

Both Cabiljau personally and the Gothenburg company more generally quickly became involved in financing Swedish war efforts. In September 1605, Charles IX's army was annihilated at the battle of Kirkholm, near Riga, which resulted in the death of some 6000-8000 men, and the loss of over $1 \%$ of the domestic male population. ${ }^{35}$ To make up for these losses and improve the obviously poor quality of its remaining forces, Sweden initiated unprecedentedly vast recruitment of foreign soldiers. At this time, the United Provinces were at the centre of an international military market in professional soldiers and military equipment, as well as a 'school of war', where the latest tactics and military science were learned and practised. ${ }^{36}$

34 Erik Thomson, 'Swedish Variations on Dutch Commercial Institutions 1605-1655', Scandinavian Studies, 77 (2005), 336; Stiernman, Sweriges Rikes, vol. 1, pp. 538-40.

35 This percentage is based on Jan Lindegren's estimates for a population of 1.2 million. Julius Mankell, Uppgifter rörande Svenska Krigsmagtens styrka, sammansättning och fördelning sedan slutet af femtonhundratalet (Stockholm: C.M. Thimgren, 1865), pp. 11, 20-21, Appendix 8; Jan Lindgren, 'Men, Money, and Means', in War and Competition between States, ed. Philippe Contamine (Oxford: Oxford University Press, 2000), p. 133.

36 David Parrott, The Business of War (Cambridge: Cambridge University Press, 2012), pp. 212-19; Sveriges Krig 1611-1632, p. 329; Marianne Klerk, 'The "fiscal-military hub" of Amsterdam: intermediating the French subsidies to Sweden during the Thirty Years' War' in Subsidies, Diplomacy, and State Formation in Europe, 1494-1789: Economies of allegiance, ed. by Svante Norrhem and Erik Thomson (Lund: Lund University Press, 2020); Peter H. Wilson and Marianne Klerk, 'The business of war untangled: Cities as fiscal-military hubs in Europe (1530s-1860s)', War in History (2020), 1-24. 
This recruitment was financed primarily through the sale of Swedish copper and iron, supplemented by agricultural produce and various lumber products required for shipbuilding; in short, the kinds of wares sought on the Amsterdam market. In return, the Crown required cash in Amsterdam or other Western European ports, where the recruits were to receive their muster money prior to boarding ships for Sweden. This operation quickly ran into difficulties, as royal agents failed to find buyers and had trouble organising transactions in a timely and secure manner. In this unique situation, Cabiljau and his associates were ideally placed to offer their expertise, credit and business network to the service of the Swedish king. ${ }^{37}$

In this system, Cabiljau and his coterie of Dutch-Swedish business people undertook the sale and export of royal wares at their own risk against a guaranteed delivery of an agreed sum of funds by a specific date in Amsterdam or elsewhere. Moreover, through their network and personal reputation, Cabiljau and his associates could perform these transactions on credit, transferring required funds swiftly by vexel (bill of exchange), without the need to wait for their sale and in many cases before they had even been delivered to the merchants. As early as August 1607, after the Crown had failed to deliver funds by other means, Abraham Cabiljau became involved. Together with his associate Wilhelm von Danzig, the merchant agreed to deliver 14,400 Swedish riksdalers in Amsterdam against future repayment in copper and other wares. This was soon followed by another payment of 13,200 Swedish riksdalers in Hamburg, and an even larger delivery of 45,600 Swedish riksdalers in the name of the Gothenburg company the following year. It was a significant improvement on the meagre trickle of cash the Crown had arranged in 1606 and earlier in 1607. Cabiljau also facilitated recruitment by other means, such as by using his business diplomacy to identify and successfully bribe the proper port officials in Amsterdam, thereby permitting the export of troops contrary to official sanctions. ${ }^{38}$

37 Jaakko Björklund, 'Officers as creditors during the Ingrian war 1609-1617', in Civilans and Military Supply in Early Modern Finland, ed. by Petri Talvitie and Juha-Matti Granqvist (Helsinki: Helsinki University Press, 2021).

38 Jaakko Björklund and Sebastian Schiavone, 'Networks of Recruitment: FiscalMilitary Operations to Contract Foreign Soldiers for Sweden 1605-1610', Northern 
Cabiljau's involvement in the recruitment operation was a mutually beneficial solution, and the Crown gained security and efficiency, besides which the recruitment process became easier to manage. In return, Cabiljau became an indispensable and favoured partner of the Swedish Crown and a significant exporter of key wares. Cabiljau also benefited from significant additional benefits when conducting the king's business, such as freedom from Swedish tolls, frequent use of royal ships and their crew to export these wares, as well as the right to profits from the sale of royal wares abroad (the wares had list values in Sweden). ${ }^{39}$

Based on the somewhat incomplete account of the Crown's debts to Cabiljau, during the period 1607-1610 alone, the merchant provided at least 113,920 Swedish riksdalers in cash for the recruitment of troops and the needs of the court. ${ }^{40}$ In return, Cabiljau received 98,284 Swedish riksdalers worth of wares and cash, including over 744 skeppund (126.5 tons) of copper worth 42,050 Swedish riksdalers, 2,760 sable furs worth 17,902.5 Swedish riksdalers (received as war profits from the army fighting in Russia), two ships and a multitude of other wares. At the end of 1610, the Crown was still indebted 15,636 Swedish riksdalers, for which Cabiljau received the right to levy rent on seventeen farms as well as toll rights to the bridge and mill at Lilla Edet, thus yielding a secure revenue estimated at 520 Swedish riksdalers annually, while also binding Cabiljau more tightly into Swedish service. ${ }^{41}$ Cabiljau continued to finance the Crown and the army as well as to maintain

Studies, 51 (2021). For Cabiljau's involvement, see for example: Letters from Abraham Cabeliau to Karl IX, 18 Feb. 1608, 11 March 1608 (Riksarkivet, Skrivelser till konungen, Skrivelser till Karl IX, vol. 5); Letter from Karl IX to Hans Nilsson and Augustino Cassiodoro, 28 Feb. 1608 (Riksarkivet, Riksregistratur); Letter from Hans Nilsson to Karl IX, 23 Sep. 1607 (Diplomatica Hollandica, Svenska beskickningars till Holland brev och arkiv, Svenska sändebud m.fl. 1592-1625, fol. 145); Abraham Cabeliaus räckning för Anno 1607, 1608, 1609 och 1610, Riksarkivet, Kammarkollegiet Ämnessamlingar, Kammarkollegiet skuldböcker (hereafter cited as Abraham Cabeliaus räckning 1607-1610), vol. 5, fols 665-72.

39 Björklund and Schiavone, 'Networks of Recruitment'.

40 Abraham Cabeliaus räckning 1607-1610, vol. 5, fols 665-72.

41 These accounts are unfortunately somewhat incomplete, as they merge several accounts and omit information. As a result, Cabiljau's personal involvement could have been broader. Abraham Cabeliaus räckning 1607-1610, vol. 5, fols 665-72. 
his central position in the web of relations between Sweden and the United Provinces until at least $1623 .^{42}$

Abraham Cabiljau does not appear to have been particularly wealthy prior to his involvement in Swedish war financing. It is unclear how exactly he financed his investments, but it seems that he was financially supported by his mercantile connections and family in Amsterdam. For example, in 1613, Cabiljau bought shares in a ship skippered by Willem Claesen from Amsterdam to sail to Sweden. ${ }^{43}$ The scattered information from the notarial deeds shows that Cabiljau and his brother Jonas, together with the Amsterdam merchants Leonard Rans and Hans Honger, had in 1608 invested money in a partnership to trade with Gothenburg. ${ }^{44}$

Cabiljau's connections to Amsterdam were wide-ranging and extensive, as exemplified by his relationship with his fellow Gothenburg migrant and administrative colleague Peter Coymans. The Coymans family had an expansive international trading network, with branches of the family stationed in numerous European cities. The family was also investing in several Nordic trading companies by funding key individuals, who in turn became the family's agents within the company. ${ }^{45}$ Raimond Veenstra argues that Cabiljau was likely involved in Coymans family operations and, alongside Peter Coymans, represented the family in Gothenburg. ${ }^{46}$ This interpretation is supported by a report from the Swedish commissary Hans Nilsson, in which Nilsson mentions an

42 Abraham Cabeliaus räckning RA, Kammarkollegiet Ämnessamlingar, Kammarkollegiet Skuldböcker, SE/RA/522/22/1 (1600-1661); Abraham Cabeliaus räckning 1623, Kammarkollegiet Ämnessamlingar, Kammarkollegiet Skuldböcker, SE/RA/522/22/3 (1595-1638).

43 SAA NAA, 132, fol. 186, 19 Sep. 1618.

44 The original document used the word company, but it was more likely to have been a trading partnership. SAA NA, 270, fol. 199, 17 Aug. 1613. Also, Veenstra has discovered this partnership, Veenstra, 'Göteborgs första handelskompani', ftn. 70.

45 Wirta, Early Modern Overseas, chapter 4.

46 As Veenstra argues, it has not been proven that they were related, but Abraham's mother Anna van der Bruggen had the same last name as Jeronimus van der Brugge, who had married into the Coymans family. It was common for the immigrant communities to marry amongst themselves, something that has been well documented in the research. Veenstra, 'Göteborgs första handelskompani', 122-24. 
attempt to negotiate a loan from an Amsterdam-based company that had sent Cabiljau to Sweden. ${ }^{47}$

In early modern Europe, such broad representation was quite common and could prove beneficial to international merchant families like Coymans and Cabiljau, who wished to gain new markets. At the same time, this two-way representation also advanced the interests of the Swedish king. ${ }^{48}$ In this sense, Cabiljau was brokering between the Swedish Empire and the international business networks of wealthy merchants from the Low Countries, and it is a testimony to Cabiljau's skill in business diplomacy that he could make this work to everyone's benefit while at the same time making himself indispensable to the operation.

Cabiljau's brokering and input were also acknowledged by the Swedish king, and in 1609, he was appointed mayor of Gothenburg while also being made responsible for the mint. In short, Cabiljau had quickly risen through the ranks to become a central figure in the initial development phase of Swedish international trade. ${ }^{49}$

\section{LEGAL BORROWING FROM THE DUTCH EMPIRE}

The legacy of Cabiljau's business diplomacy is particularly evident in the development of Swedish commercial law. When Cabiljau migrated to Sweden, he encountered not only a foreign climate and language but also unfamiliar approaches to commercial legislation. International commercial contracts created in Sweden were far more rudimentary than those used within the Dutch Empire. ${ }^{50}$ Over the centuries, Swedish

${ }^{47}$ Letter from Hans Nilsson to Karl IX, 14 Oct. 1607, Riksarkivet, Diplomatica Hollandica, Svenska beskickningars till Holland brev och arkiv, Svenska sändebud m.fl. 1592-1625, fols 146-47.

${ }^{48}$ At this time, doctor Jacob van Dijck was appointed Swedish ambassador to the Dutch Republic and France while continuing to operate as a Dutch merchant, and Sir James Spens operated as official Swedish ambassador to Great Britain as well as British ambassador to Sweden.

49 Cátia Antunes has shown that adaptability within the host society, access to local power holders and broad international networks capable of providing social and economic support were the cornerstones of early modern business diplomacy. Antunes, 'Early Modern Business Diplomacy', 23.

50 Villstrand, Sveriges historia, p. 478. 
commercial legislation had developed to serve local traders by regulating Swedish trading conditions, such as marketplaces, taxes and sales articles. ${ }^{51}$ Cabiljau and his business connections, who proposed forming trading companies, were unfamiliar with Swedish law and needed to adapt to Swedish commercial legislation. The critical question thus became how to administer international trade. Initially, Cabiljau and his associates imported borrowed or copied administrative structures from the Republic. ${ }^{52}$

Legal matters frequently became enmeshed with business diplomacy since expertise and advanced legal knowledge, often more than one individual could be expected to provide, were required. In this regard, Cabiljau enlisted the aid of Jacob van Dijck, a doctor in law from the University of Leiden. ${ }^{53}$ Van Dijck acted as Cabiljau's advisor in legal matters and made an outstanding contribution to drafting the charters for the new town of Gothenburg and its trading company. Together, Cabiljau and van Dijck introduced central European juridical manners, culture and expertise, thereby significantly influencing the formation of the Swedish Empire during its early stages. ${ }^{54}$

It is safe to assume that Van Dijck also assisted Cabiljau in shaping the company's structure following a model borrowed from the Dutch East India Company (VOC). The general organisation of the company, which Cabiljau and his network proposed and carried out, followed the contemporary Dutch model. Cabiljau and Coymans also invested some capital in the VOC, which suggests that they had a connection with the Dutch forerunner. ${ }^{55}$

51 Tikka, Laivojen tuomaa lakia, p. 2; Sandström, Mellan, pp. 40-57.

52 Legal borrowing is a common phenomenon between organisations. It also occurred within Dutch companies. Dave de ruysscher, 'Chartered Companies in Sweden, the Dutch Republic and England (c. 1600 - c. 1630): Experimenting in Corporate Governance', in The Development of Commercial Law in Sweden and Finland (Early Modern Period-Nineteenth Century), ed. by Katja Tikka (Leiden: Brill, 2020), p. 73.

53 About Van Dijck, see Fröding, Berättelser, pp. 31-35.

54 D. Hoek, 'Jacob Dijck van', in Svenskt biografiskt lexikon, https://sok.riksarkivet. se/sbl/artikel/17538 (accessed 20 Nov. 2020); Per-Gunnar Ottosson and Heimut Backhaus (eds), Rikskanslern Axel Oxenstiernas skrifter och brevväxling, utgivna av Kungl. (Stockholm: Vitterhets Historie och Antikvitets Akademien i samarbete med Riksarkivet, 2012), Letter by Salvius.

55 Veenstra, 'Göteborgs första handelskompani', 120-21. 
Considering the early success of the VOC, it is hardly surprising that the Swedish Crown had similar expectations for the Swedish company. The success of the VOC was based on its practical and well-organised management structure as well as its almost complete autonomy from the state, which provided significant leeway in practising business and empire in Asia. Although the idea was to copy some parts of the Dutch model, this proved difficult since the management of the VOC was based on chambers representing the seven provinces of the Northern Netherlands. ${ }^{56}$

The charter (patent) of 1607 is a prime example of copying from Dutch models in a Swedish context. The concept of legal transplant ${ }^{57}$ or legal borrowing can help to explain this phenomenon. ${ }^{58}$ Initially, the company tried to follow the chamber model, whereby a chamber was supposed to be established in every town where the company did business. Shareholders offered their capital to the company so that it could be invested in trading voyages. Dividends could not be recovered until twelve years after the beginning of operations, but investors were promised a considerably high return of twelve per cent after the first two years. Further, company finances were based on a pro-rata principle, with investors receiving returns in relation to their invested sum. ${ }^{59}$

This kind of long-term oriented business, with pooled capital, was new in Sweden and thus difficult to transfer. This fact also ensured

${ }^{56}$ Ella Gepke-Jager, 'Verenigde oost-indische compagnie', in Ella Gepke-Jager, Gerard van Solinge, Levinus Timmerman (eds), VOC 1602-2002, 400 Years of Company Law. Law and Business and Finance, vol. 6 (Kluwer Legal Publishers, 2005), pp. 48, 63-64; Femme Gaastra, 'The Shifting Balance of Trade of the Dutch East India Company', in Companies and Trade: Essays on Overseas Trading Companies during the Ancien Régime, ed. by Leonard Blussé and Femme Gaastra (Leiden: Leiden University Press, 1981), pp. 149-50.

57 The term 'legal transplant' means that a rule or a system of law is copied from one country to another. Thomas Duve, 'European Legal History - Concepts, Methods, Challenge', in Entanglements in Legal History: Conceptual Approaches, ed. by Thomas Duve (Frankfurt am Main: Max Planck Institute for European Legal History, 2014), p. 11.

58 Stiernman, Sweriges Rikes, vol. 1, pp. 538-40.

59 De ruysscher, 'Chartered Companies', pp. 82-84; Stiernman, Sweriges Rikes, vol. 1, pp. 538-40; Tikka, Laivojen tuomaa lakia, p. 47. 
the company's downfall since local traders either remained suspicious towards the model or lacked sufficient means to invest. The outcome was the same: very few, if any, Swedes invested in the company. As this demonstrates, the success of early modern legal transplants was closely dependent on local circumstances and culture. In this case, early attempts at legal transplant did not succeed in Sweden. ${ }^{60}$

In addition, various other significant political and juridical differences also impacted the success of the transplant. Firstly, the structure of the Swedish state and the role of the Swedish ruler within it varied greatly from the Dutch Republic. In comparison to the latter, Sweden was more centralised with a relatively powerful king. The nobility had influence, but the group was small, and burghers as a social group were even smaller. The intentions of the king and his foreign experts were also somewhat conflicted. Foreign merchants formulated the structure of the Gothenburg company to serve their own purposes, focusing on commercial activities in Muscovy, Persia and the east more generally, rather than in Sweden. ${ }^{61}$

The company's charter outlined its activities only in simple terms. There were few mentions of the company's role, authorities, shareholders' rights, profit sharing, or of the Crown's officials. ${ }^{62}$ The legal terminology of the charter was still relatively unknown in Swedish and effectively introduced a new vocabulary into the country. This was a further means by which the legal transplant, mediated through foreign expertise, impacted commercial law development in the Swedish Empire. Only after the establishment of several other commercial companies in Sweden did this new legal language take root. ${ }^{63}$

Despite attempts by Cabiljau, van Dijck and their associates, the fire of Gothenburg in 1611 and the beginning of the Kalmar War the same

${ }^{60}$ Duve, European Legal History, p. 11; Michele Graziadei, 'Comparative Law, Transplants, and Receptions', in The Oxford Handbook of Comparative Law, ed. by Mathias Reimann, Reinhard Zimmermann (Oxford: Oxford University Press, 2019), pp. 442-44, 468.

${ }^{61}$ Jacobson, 'Abraham Cabiljau'.

62 Stiernman, Sweriges Rikes, vol. 1, pp. 538-40.

${ }^{63}$ De ruysscher, 'Chartered Companies', pp. 71-74; Tikka, Laivojen tuomaa lakia, pp. 222-27. 
year severely damaged the company's prospects. ${ }^{64}$ As a consequence of the increasing centralisation of power around the king, his interest slowly shifted from Gothenburg to Stockholm. By the 1620s, the capital had become the primary location for further developments of commercial law.

\section{RELOCATION TO STOCKHOLM}

During the final years of the first decade of the seventeenth century, Cabiljau decided to move back to Amsterdam. While in Amsterdam, Cabiljau remained involved in international trade between Sweden and the Dutch Republic. For example, he bought bottomry bonds in several Amsterdam ships engaged in trade between Amsterdam and Gothenburg. In 1625, Cabiljau was involved in the transportation of salted herring from Stockholm to Amsterdam. ${ }^{65}$

In 1621, Cabiljau moved back to Sweden at the invitation of High Chancellor Oxenstierna. However, Cabiljau settled in Stockholm this time, where King Gustav II Adolf offered him a leading position in the economic sector. Amongst other things, he became the general accountant of the state, with responsibility for the state's bookkeeping. In this capacity, Cabiljau carried out the first complete audit of the Swedish state in 1623, thus pioneering in developing double-entry bookkeeping in Sweden. ${ }^{66}$

Cabiljau's proximity to the ruling authorities of Sweden is most evident from his social network. It was typical for merchants from Amsterdam to aim towards social advancement through marriage with someone of equally high or preferably higher status. It was also common to include family in the enterprise. Abraham's brothers and son were all involved in the Dutch-Swedish trade, and his daughter Margareta Slots

${ }^{64}$ In 1612, the Danish army had attacked and conquered Gothenburg and the Älvsborg castle, and in the peace treaty of Knäred, Sweden was obliged to pay a ransom of one million rixdalers.

65 SAA NA, 132, fol. 186, 19 Sep. 1613; SAA NA, 591, fol. 148, 1 Apr. 1625.

${ }^{66}$ Appointment letter of A.C. as the accountant 1 May 1624. Abraham Cabeliaus räckning RA, Kammarkollegiet Ämnessamlingar, Kammarkollegiet Skuldböcker, SE/RA/522/22/1 (1600-1661); Risto Marjomaa, 'Adler Salvius, Johan', https:// kansallisbiografia.fi/kansallisbiografia/henkilo/3238 (accessed 20 Nov. 2020); Fröding, Berättelser, p. 50. 
became the mistress of King Gustav II Adolf. ${ }^{67}$ As explained earlier in this article, Abraham and his brother Jonas had conducted trade with Sweden since 1607. In 1622, Jonas collaborated with their cousin Jan Weijten, establishing together with the Amsterdam merchants Pieter Denijs, Abraham Willems van Beijerland and Jan van Harinckhoeck a trading company for commerce with Sweden. Jonas Cabiljau led the company from Amsterdam, and Abraham Willems was appointed bookkeeper. The participants were to invest 7000 carolusgulden and remain responsible for providing the cargo (goederen en coopmanschappen) for the ships to Sweden and for organising the distribution of the return cargo. ${ }^{68}$

Like his father, Cabiljau's son Johan was educated in Leiden and undertook an apprenticeship in Stockholm, working in the same chamber as his father. However, Johan eventually returned to the Republic, where he became a scholar and taught several Swedish officials. In this way, the connections between the Cabiljau family and the empire remained intact, encompassing not only business but also education and knowledge.

During his second residence in Sweden, Cabiljau once again worked on developing trading companies. At Gustav II Adolf's insistence, a new Ship Company (skeppskompaniet) was formed in 1629. The company was an expression of the king's grandiose imperial and global ambitions, and particularly his objective of building up Swedish mercantile shipping in the Atlantic and globally, thereby reducing dependency on Dutch and other foreign shipping, as well as providing a fleet of sixteen armed merchant vessels that could reinforce the royal navy on request. ${ }^{69}$ Potential enemies included not only Denmark as a Baltic Sea rival but also the naval superpower Spain, which the king was prepared to challenge on the high seas given Sweden's involvement in an anti-Habsburg coalition during the Thirty Years' War. The Council of the Realm had

67 About Margareta Slots, see Svante Norrhem, Margareta Slots (Margareta Cabiljau), transl. by Alexia Grosjean, https://skbl.se/en/article/MargaretaSlots (accessed 16 Nov. 2020).

68 SAA NA, 200, fols 185v-88, 16 Apr. 1619.

69 Arming the vessels was also motivated by the hazards posed by pirates, privateers and hostile navies in long-distance trade, but also gave Swedish merchants the means to engage in privateering if needed. Jan Glete, Swedish Naval Administration 1521-1721 (Leiden: Brill, 2010), p. 434. 
their reservations regarding the new venture, yet nonetheless set about implementing the king's will. During these discussions, Admiral Claes Fleming suggested that the best structure for the new company would be to appoint Dutchmen as directors accompanied by one or two nobles. Indeed, even the Council of the Realm recognised the expertise and capacity of Dutch merchants, which it hoped would help avoid the pitfalls of the previous companies and provide the knowledge and connections needed for expansion into the Atlantic. ${ }^{70}$

Already well-established in Sweden, possessing intimate knowledge of the Atlantic trade and Dutch corporate models and enjoying royal favour, Cabiljau was the natural choice to lead the new company and supervise Sweden's foreign trade. In 1630, he was granted power of attorney to organise the merger of the South Company with the Ship Company. ${ }^{71}$ This included establishing the structure and organisation of the new company, as well as the rearrangement of its capital. The operation seems to have proceeded smoothly, as the king then appointed Cabiljau 'general director' (governor) of the new company. This position as head of the directors also granted Cabiljau the office of 'commissaris', making him responsible for appointing necessary personnel, managing the accounting and overseeing daily administration. ${ }^{72}$

As Dave De ruysscher has shown, the idea of a General Director also came from abroad, not from the Dutch context but rather from the English, where the idea of a governor had already been present in the Company of Merchant Adventurers. ${ }^{73}$ This demonstrates the broad spectrum of ideas that circulated during the development of Swedish international commerce. For Cabiljau, this was undoubtedly beneficial since it strengthened his position in Sweden. He was at all times responsible for supervising the company and upholding the interests of the investors and the kingdom. ${ }^{74}$ Administration of such an enterprise

70 Nils Axel Kullberg, Svenska Riksrådets Protokoll, 1630-1632 (Stockholm: Kongl. Boktryckeriet 1880), 14 Oct. 1631, pp. 116-18; Villstrand, Sveriges historia, p. 478; Glete, Swedish Naval Administration, pp. 338-39, 385-94, 403-12, 434-38.

71 Privileges for the company 1629, Stiernman, Sweriges Rikes, vol. 1, p. 973.

72 'Fullmacht för Abr. Cabeliau 1630', in Stiernman, Sweriges Rikes, vol. 1, pp. 989-90.

73 De ruysscher, Chartered Companies, pp. 71, 79-80.

74 Stiernman, Sweriges Rikes, vol. 1, pp. 989-91. 
required experience in international trade, including running daily operations and the cultivation of vast networks of trade connections - key features in business diplomacy. The career progression of Cabiljau also indicates a change from being a broker between international business networks and the king towards direct service of the Swedish Empire as such. Such invitations and positions underscore that his experience and knowledge in trade were highly appreciated in Sweden.

The hybrid character of Cabiljau's expertise became even more apparent when he joined the small group of 'goodmen' (godemän - goede mannen) who served as close advisors to the king. Indeed, this concept was another import from the Dutch administrative framework. ${ }^{75}$ Due to his experience with international settings, the king considered Cabiljau to be consulted in complicated international legal affairs.

This trust was exemplified in May 1631, when Cabiljau and his colleagues Jacob Feiff and Valentin Nilsson were asked to investigate a ship that had sailed from Archangelsk to the Dutch Republic and, after that, to Spain before returning to Holland. Apparently, the ship carried a false Gothenburg license that had been counterfeited in Holland. After the investigation, Nilsson and Cabiljau found the skipper guilty of sailing with false papers. ${ }^{76}$ This issue was directly related to the political tension between Spain and the Dutch Republic; as Dutch ships could not trade with Spain, a Swedish passport was used to circumvent the prohibition. Investigating such transgressions required expertise and knowledge of how these types of activities were conducted in practice. In other words, Cabiljau's expertise was broad and clearly recognised.

\section{CAREER LIMITATIONS}

In October 1631, a meeting of the Council of the Realm was held, at which Cabiljau and Nilsson reported that there were seven ships ready to sail to Spain or France. However, the company lacked the capital to fit

75 Henri Hannula, 'Commercial Diplomacy from Below: Dutch Baltic Merchants as an Economic Interest Group in Dutch-Swedish relations 1675-1688', Tijdschrift voor Zeegeschiedenis (forthcoming 2021); Tielhof, Mother of All Trades, p. 125.

${ }^{76}$ RP, 18 May 1631, pp. 91-92. 
out the ships. Cabiljau suggested to the Council that the Crown could invest in equipping the ships or that it would be possible to partner with a French merchant if the ships were to sail to France. ${ }^{77}$

Eventually, in 1632, four company ships departed for Spain. However, the ships were seized by Spanish privateers in retaliation for Swedish entry into the Thirty Years' War in 1630. Gustav II Adolf planned to retaliate by attacking Spanish Atlantic shipping but was killed at Lützen before this could occur. The Council of the Realm, less enthusiastic about the Atlantic adventure and eager to cut costs, changed policy. Rather than escalate the naval war against Spain, the Council decided to focus on the Baltic Sea and the ongoing war in Germany instead. With his royal patron gone and lacking aristocratic supporters, Abraham Cabiljau soon became the scapegoat for the failed venture. ${ }^{78}$

The loss of half of the company's ships raised concerns regarding the company's management, and legal proceedings were opened against Cabiljau regarding accusations that he had misused his position. Investors wanted compensation from the Crown, the Council of the Realm accused the directors, and the directors were caught in the middle. Cabiljau's office was raided and his papers confiscated. The director was accused of operating only for Dutch interest and of having ruined the company fleet through his decision to allow ships to sail to Spain. Indeed, at the time, several trade ventures from Sweden and Denmark had close connections to Amsterdam business networks, and the private interest of the merchants and the interest of the Crown did not always overlap. ${ }^{79}$

In his defence, Cabiljau maintained that he had sought state approval for the venture and had not acted independently. Cabiljau had written permission from the Spanish duke Medina Sidonia to conduct the trade and provided letters showing that the duke and a few other merchants from Spanish-controlled Antwerp were interested in participating in the company itself. The king had reviewed these documents and, convinced by these guarantees, had licensed the venture, stating that

77 RP, 14 Oct. 1631, pp. 116-18.

78 Glete, Swedish Naval Administration, pp. 406-12, 437-38.

79 Nils Axel Kullberg, Svenska Riksrådets Protokoll, 1633 (Stockholm: Kongl. Boktryckeriet, 1885), 12 March 1633, p. 71; 26 Nov. 1633, p. 250. 
'the world is big enough, and they could follow the example of others and be allowed to sail'. ${ }^{80}$

Cabiljau further defended himself by stating that his factor in Spain would assist in the matter by retrieving the confiscated ships. According to Cabiljau, his factor would sail with his own ship and rendezvous with the company ships to assist them with the Spanish authorities. Cabiljau tried to ensure that there would be no further issues with Spain, but even his colleague Nilsson alleged that he lacked proof of actually having the necessary contacts in Spain. ${ }^{81}$ The matter was complicated by Swedish participation in the war, which had soured relationships with the Habsburgs and, by extension, compromised sailing to Spain.

The concerns of Nilsson and others were justified, and the lost ships were never returned. Following the death of the king in 1632, the director could no longer call on royal support and was left at the mercy of his opponents, who held him accountable. Until his death in 1645, Cabiljau remained in a dispute with the company. ${ }^{82}$ In 1650, five years after his death, Cabiljau was acquitted of these charges and his family was freed from the obligation to repay the losses. ${ }^{83}$ The final traces from the notarial archives in Amsterdam show that prior to his death, he was involved in Atlantic trade through organising bottomry bonds for the transportation of sugar from Reciefe (Brasil) to Amsterdam. Until the end, he thus remained active in international business, and his long career encapsulated the many segments of which international trade was composed. ${ }^{84}$ However, his actions were limited because the Swedish state was still transitioning from an early modern into a modern state.

\section{CONCLUSION}

Abraham Cabiljau's career illustrates the importance of business diplomacy as practised by free agents, who possessed general competence,

80 'Verlden är vijdh nogh; the kunne som andra försökja sigh', RP, 26 Nov. 1633, pp. 249-51; RP, 05 Dec. 1633, pp. 266-67.

${ }^{81}$ RP, 20 Dec. 1633, pp. 292-93.

${ }^{82} \mathrm{He}$ is buried at Riddarholmskyrkan in Stockholm.

${ }^{83}$ Severin Bergh, Svenska Riksradets Protokoll, 1650 (Stockholm: Norstedt, 1916), 20 March 1650, p. 88.

84 SAA NA, 602, fol. 206, 19 Jan. 1644. 
navigated and negotiated between northern European empires, for commercial, legal and administrative developments in Sweden. In the Swedish Empire, Cabiljau was involved in several different sectors, from military recruitment to the development of state accounting and the administration of international trade. The knowledge he transferred to Sweden in the development of bookkeeping shows the importance of business diplomacy for the Swedish Empire. Unlike the company trade, bookkeeping soon came to be widely practised within the state bureaucracy. He embodies the vast and expansive economic relationships that the Swedish Empire maintained with international merchant networks in a broad spectrum of military and commercial arenas.

As has been shown, the Swedish Empire was economically dependent on the financial resources of the merchants in Amsterdam. In fact, loans provided by these merchants not only made economic growth in Sweden a reality but also helped to turn Sweden into a Northern Empire. Furthermore, Cabiljau's career demonstrates that economic prosperity was not the sole contribution of these merchants. The education, knowledge and connections provided by Cabiljau greatly enhanced the administration and organisation of Sweden's international trade by importing a new legal mindset and administrative culture. In turn, northern mining resources and Baltic commerce were alluring for Dutch merchants, as was the prospect of practising international trade under the protection of the Swedish king. Sweden provided incentives for Cabiljau that were difficult to ignore.

By analysing the business diplomacy practised by Cabiljau, this article has argued that the modelling of organisations was an essential part of Swedish economic development. Cross-imperial connections were natural as well as inevitable, and although the United Provinces was a good model to emulate, it was not the only option available. There was no guarantee that foreign structures would work in Sweden; often, they required considerable local adaptation. As the Gothenburg Company and the Ship Company demonstrate, the decisive role of the king and the centralised state combined with Sweden's weak merchant class and lack of capital inhibited the transfer of purely Dutch corporate models. However, building these organisations in an alien environment created opportunities for new ideas. In the long run, the effort put into 
developing these organisations was more important than their prosperity, helping lay the groundwork for Sweden's subsequent expansion.

The multiple roles, general competence, and career path of Cabiljau also demonstrate that the goals of individuals representing the empire, the king, and the state could differ from and grow to become part of the empire as a plural. Initially, Cabiljau represented, first and foremost, his business connections in Amsterdam. Eventually, he became closer to the king, and his imported knowledge and skills slowly started to benefit the development of the Swedish business sector. Thus, although the companies studied here remained an experimental attempt to transplant the model of the VOC into Sweden, individuals like Cabiljau were nonetheless key actors who initiated, taught and promoted the development of commercial law in Sweden, as well as bringing Nordic politics into connection with the growing European expansion overseas.

\section{BIBLIOGRAPHY}

\section{Archival Sources}

Nationaal Archief, Den Haag, Staten-Generaal,

nummer toegang 1.01.02, inventarisnummer 12563.2

Stadssarchief Amsterdam, Notarieel Archief,

SAA NA, 218, fol. 97, 30 May 1622.

SAA NA, 270, fol. 199, 17 Aug. 1613.

SAA NA, 132, fol. 186, 19 Sep. 1613.

SAA NA, 200, fol. 185v, 16 Apr. 1619

SAA NA, 200, fols 185v-188, 16 Apr. 1619

SAA NA, 658, fol. 662, 28 June 1622

Riksarkivet, Stockholm, Kammarkollegiet Ämnessamlingar, Kammarkollegiet skuldböcker, vol. 5

Riksarkivet, Stockholm, Skrivelser till konungen, Skrivelser till Karl IX, vol. 5;

Riksarkivet, Stockholm, Riksregistratur

Riksarkivet, Stockholm, Diplomatica Hollandica, Svenska beskickningars till Holland brev och arkiv, Svenska sändebud 


\section{Printed Primary Sources}

Bergh, Severin, Svenska Riksrådets Protokoll, 1650 (Stockholm: Norstedt 1916) Kullberg, Nils Axel, Svenska Riksrådets Protokoll, 1630-1632 (Stockholm: Kongl. Boktryckeriet 1880)

, Svenska Riksrådets Protokoll, 1633 (Stockholm: Kongl. Boktryckeriet 1885)

Lindberg, Folke and Folke Sleman Privilegier, resolutioner och förordningar for Sveriges städer IV (1592-1611) (Stockholm: Stadshistoriska institutet, 1949)

Ottosson, Per-Gunnar and Heimut Backhaus (eds), Rikskanslern Axel Oxenstiernas skrifter och brevväxling, utgivna av Kungl. (Stockholm: Vitterhets Historie och Antikvitets Akademien i samarbete med Riksarkivet, 2012)

Stiernman, Anders Anton von, Sweriges Rikes commerce, politie och oeconomie uti gemen uppå Hans Kongl. Maj:ts nodigsta belfallning. Första delen (Stockholm: Kong. trykeriet., 1747)

\section{Secondary Works}

Almquist, Helge, Göteborgs historia: grundläggning och de första hundra åren (Göteborg: Göteborgs litografiska aktiebolag 1929)

Andersson, Bertil, Martin Fritz, Kent Olsson, Göteborgs historia. Näringsliv och sambällsutveckling: 1 Frän fästningsstad till handelsstad 1619-1820 (Stockholm: Nerenius \& Santérus, 1996)

Antunes, Cátia, 'Early Modern Business Diplomacy: An Appraisal', Diplomatica, 2, no. 1 (2020), 20-27

'Free Agents and Formal Institutions in the Portuguese Empire: Towards a Framework of Analysis', Portuguese Studies, 28, no. 2 (2012), 173-85

Björklund, Jaakko and Sebastian Schiavone, 'Networks of Recruitment: Fiscal-Military Operations to Contract Foreign Soldiers for Sweden 1605-1610', Northern Studies, $51(2021)$

Björklund, Jaakko, 'Officers as creditors during the Ingrian war 1609-1617', in Civilans and Military Supply in Early Modern Finland, ed. by Petri Talvitie and Juha-Matti Granqvist (Helsinki: Helsinki University Press, 2021)

Dahlgren, Erik Wilhelm, Louis de Geer, 1587-1652, hans lif och verk, vol. 2 (Uppsala: Almqvist och Wicksell, 1923)

Dalhede, Christina, Viner, Kvinnor och kapital (Partille:Warne förlag, 2006)

De ruysscher, Dave, 'Chartered Companies in Sweden, the Dutch Republic and England (c. 1600 - c. 1630): Experimenting in Corporate Governance', in The Development of Commercial Law in Sweden and Finland (Early Modern PeriodNineteenth Century), ed. by Katja Tikka (Leiden: Brill, 2020)

Duve, Thomas, 'European Legal History - Concepts, Methods, Challenge', in Entanglements in Legal History: Conceptual Approaches, ed. by Thomas Duve (Frankfurt am Main: Max Planck Institute for European Legal History, 2014)

Fröding, Hugo, Berättelser ur Göteborgs äldsta historia (Göteborg: Wald. Zachrissons förlag, 1908) 
Gaastra, Femme, 'The Shifting Balance of Trade of the Dutch East India Company', in Companies and Trade: Essays on Overseas Trading Companies during the Ancien Régime, ed. by Leonard Blussé and Femme Gaastra (Leiden: Leiden University Press, 1981)

Gepke-Jager, Ella, 'Verenigde oost-indische compagnie', in Ella Gepke-Jager, Gerard van Solinge, Levinus Timmerman (eds), VOC 1602-2002, 400 Years of Company Law. Law and Business and Finance, vol. 6 (Kluwer Legal Publishers, 2005)

Glete, Jan, Swedish Naval Administration 1521-1721 (Leiden: Brill, 2010)

Graziadei, Michele, 'Comparative Law, Transplants, and Receptions', in The Oxford Handbook of Comparative Law, ed. by Mathias Reimann, Reinhard Zimmermann (Oxford: Oxford University Press, 2019)

Grosjean, Alexia and Steve Murdoch, 'The Scottish Community in Seventeenth-Century Gothenburg', in Alexia Grosjean and Steve Murdoch (eds), Scottish Communities Abroad in the Early Modern Period (Leiden: Brill, 2005)

Hannula, Henri, 'Commercial Diplomacy from Below: Dutch Baltic Merchants as an Economic Interest Group in Dutch-Swedish relations 1675-1688', Tijdschrift voor Zeegeschiedenis (forthcoming 2021)

Hulsman, Lodewijk, 'Nederlands Amazonia: handel met indianen tussen 1580 en 1680', PhD-Dissertation (Amsterdam, University of Amsterdam, 2009)

Israel, Jonathan, Dutch Primacy in World Trade, 1585-1740 (Oxford: Clarendon Press, 1990)

Jong, Michiel de, 'Dutch entrepreneurs in the Swedish Crown trade in copper and iron, 1580-1630', in Trade, Diplomacy and Cultural Exchange. Continuity and Change in the North Sea Area and the Baltic, ed. by Hanno Brand (Hilversum: Uitgeverij Verloren, 2005)

Klerk, Marianne, "The "fiscal-military hub" of Amsterdam: intermediating the French subsidies to Sweden during the Thirty Years' War' in Subsidies, Diplomacy, and State Formation in Europe, 1494-1789: Economies of allegiance, ed. by Svante Norrhem and Erik Thomson (Lund: Lund University Press, 2020)

Lappalainen, Mirkka, Maailman painavin raha: Kirjoituksia 1600-luvun Pohjolasta (Helsinki: Silatala, 2006)

Lesger, Clé, Rise of the Amsterdam Market and Information Exchange: Merchants, Commercial Expansion and Change in the Spatial Economy of the Low Countries, c. 1550-1630 transl by J.C. Grayson (Aldershot: Burlington, Ashgate, 2006)

Lindgren, Jan, 'Men, Money, and Means', in War and Competition between States, ed. Philippe Contamine (Oxford: Oxford University Press, 2000)

Lottum, Jelle van, Across the North Sea: The Impact of the Dutch Republic on International Labour Migration, c. 1550-1850 (Groeningen: Aksant Academic Publishers, 2008)

Magnusson, Lars, Sveriges ekonomiska historia (Studentlitteratur: Lund, 2016) 'Bruksmiljö och brukskultur' in Stormaktstiden, ed. by Jacob Christensson (Lund: Signum svenska kulturhistoria, 2005)

Mankell, Julius, Uppgifter rörande Svenska Krigsmagtens styrka, sammansättning och fordelning sedan slutet af femtonhundratalet (Stockholm: C.M. Thimgren, 1865) 
Müller, Leos, 'The Dutch Entrepreneurial Networks and Sweden in the Age of Greatness', in Trade, Diplomacy and Cultural Exchange. Continuity and Change in the North Sea Area and the Baltic c. 1350-1750, ed. by Hanno Brand (Hilversum: Uitgeverij Verloren, 2005)

The Merchant Houses of Stockholm c. 1640-1800. A Comparative Study of Early-Modern Entrepreneurial Behaviour (Uppsala: Uppsala University Library, 1998)

Nergård, Maj-Britt, Mellan krona och marknad: utländska och svenska entreprenörer inom svensk järnhantering från ca 1580 till 1700 (Uppsala: Acta Universitatis Upsaliensis, 2001)

Parrott, David, The Business of War (Cambridge: Cambridge University Press, 2012) Pereira, Edgar and Wirta Kaarle, 'A Forgotten Emporium: Commercial Aspirations and Transnational Mercantile Networks in Seventeenth Century Glückstadt', in Locating the Global Spaces, Networks and Interactions from the Seventeenth to the Twentieth Century, ed. by Holger Weiss (Oldenburg: De Gruyter, 2020)

Roberts, Michael, Gustavus Adolphus: A History of Sweden 1611-1632, vol. 1 (London: Longmans 1965)

Sandström, Åke, Mellan Torneå och Amsterdam: En undersökning av Stockholms roll som formedlare av varor i regional- och utrikeshandel 1600-1650 (Stockholm: Stockholmsmonografier 1990)

Söderberg, Johan, Vår världs ekonomiska historia, vol. 1: Den förindustriella tiden (Stockholm: SNS förlag, 2007)

Steensgaard, Niels, 'The Dutch East India Company as an Institutional Innovation', in Dutch Capital and World Capitalism: Capitalisme Hollondais et Capitalisme Mondial, ed. by Maurice Aymard (Cambridge: Cambridge University Press, 1982)

Thomson, Erik, 'Swedish Variations on Dutch Commercial Institutions 1605-1655', Scandinavian Studies, 77 (2005)

Tielhof, Milja van, The 'Mother of All Trades': The Baltic Grain Trade in Amsterdam from the Late 16th to the Early 19th Century (Leiden: Brill, 2002)

Tikka, Katja, Laivojen tuomaa lakia (Helsinki: Unigrafia, 2020)

Vasara-Aaltonen, Marianne, Learning Law and Travelling Europe: Study Journeys and the Developing Swedish Legal Profession, c. 1630-1800 (Leiden: Brill, 2020)

Veenstra, Raimond, 'Göteborgs första handelskompani (1606-1611): vem och varför? - Handelskolonin i Karl IX:s Göteborg betraktad ur en europeisk synvinkel', Göteborg förr och nu (Göteborg: Göteborgs Hembygdförbunds Skriftserie XXXII 2008)

Villstrand, Nils Erik, Sveriges historia 1600-1721 (Stockholm: Norstedts, 2011)

Vries, Jan de and Ad van der Woude, The First Modern Economy: Success, Failure, and Perseverance of the Dutch Economy, 1500-1815 (Cambridge-New York: Cambridge University Press, 1997)

Wilson, Peter H. and Klerk, Marianne, 'The business of war untangled: Cities as fiscal-military hubs in Europe (1530s-1860s)', War in History (2020)

Wirta, Kaarle, Early Modern Overseas Trade and Entrepreneurship: Nordic Trading Companies (New York: Routledge, 2020) 
Wrangel, Ewert, De betrekkingen tusschen Zweden en de Nedelrnaden op het gebied van letteren en wetenschap: voornamlijk gedurende de zeventiende eeuw (Leiden: Brill 1901)

\section{Online Publications}

Norrhem Svante, Margareta Slots (Margareta Cabiljau), transl. by Alexia Grosjean, https://skbl.se/en/article/MargaretaSlots (accessed 16 Nov. 2020)

Risto Marjomaa, 'Adler Salvius, Johan', https://kansallisbiografia.fi/kansallisbiografia/ henkilo/3238 (accessed 20 Nov. 2020)

Svenskt biografiskt lexikon, D. Hoek: Jacob Dijck, van, https://sok.riksarkivet.se/sbl/ artikel/17538 (accessed 20 Nov. 2020)

Svenskt biografiskt lexikon, G. Jacobson: Abraham Cabiljau, https://sok.riksarkivet.se/ sbl/artikel/16310 (accessed 16 Nov. 2020)

Kaarle Wirta $(\mathrm{PhD})$ - a specialist in early modern business history, lecturer at the Tampere University. He received his doctoral degree at Leiden University in 2018. Recently he has done research on the early modern Finnish tar trade in an international business context funded by Kone foundation (Finland); e-mail: kaarle.wirta@tuni.fi

Katja Tikka $(\mathrm{PhD})$ - lecturer of legal history at the University of Helsinki and legal culture at the University of Lapland; author of the dissertation on the first Swedish commercial companies in the 17th century. Her academic interests also cover the maritime history and the history of medicine as well as the Helsinki city history in the 19th and 20th centuries; e-mail: katja.tikka@helsinki.fi

Jaakko Björklund (MA, MSc) - PhD candidate at the University of Helsinki (Doctoral Program of History and Cultural Heritage). His research focuses on early modern military history, ranging from the history of military theory to the broader economic and social dimensions of warfare. Author of several articles on transnational recruitment networks and war financing; in his upcoming dissertation, he examines the role of military entrepreneurship in the Swedish army during the Ingrian War (1609-17); e-mail: jaakko.bjorklund@helsinki.fi 